\title{
Research on Profits Compensation caused by the Work Omission
}

\author{
Hong $\mathrm{Ke}^{\text {a }}$, Yaxin Huang ${ }^{\mathrm{a}}$ \\ School of Management, Tianjin University of Technology, Tianjin, China \\ a747697428@qq.com
}

\begin{abstract}
Based on the profit and researched its contents. Researching the contractor's profit and loss calculation method; studying the principle, the determination and the method of profit compensation in the work omission. This paper focuses on these three aspects above, especially on the determination and compensation methods of the loss of profit in the work omission, which are of great significance to improve the compensation of the contractor.
\end{abstract}

Keywords: Variation; Work Omission; Profit Compensation.

\section{Introduction}

Accompanied by a large number of construction variation occurred, the work omission also frequently appear in practice[1].In the widespread implementation of the mode of valuation with bill quantity, profit is the contractor's independent quotation, with its own management level.Due to the different quotation, therefore, in order to provide the accurate rate of profit compensation caused by the work omission for contractor, it is necessary to study the profit compensation in the contract agreement.For construction variationscaused by the work omission to contractors for compensation need to meet the conditions are too abstract and lack of implementation of standards, so contracting parties are unable to come to an agreement with the deletions of the profit compensation[2].13 list(Code of Bills of Quantities and Valuation for Construction Works), combined with related literatures and the current national laws and regulations, explored the reasons profit compensation and mechanism of determined caused by work omission, and provided the basis for the Contractor to deal with.

\section{Loss of profit compensation caused by work omission}

The contractor may apply for compensation for work omission due to the requirements of the project cost, schedule and function[3]. The regulations, norms, templates, for the work omission of the contract terms and conditions on construction variation carried out a clear agreement. As shown in Figure 1.

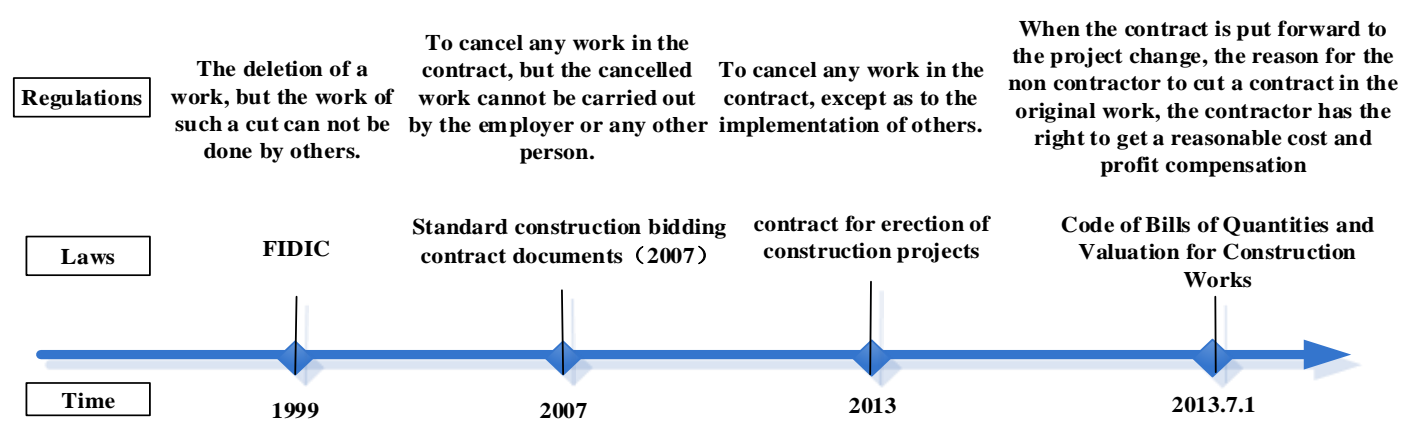

Fig. 1 The development of the relevant provisions of the work omission

According to the Figure 1, National existing laws and regulations already have a clear provision with the needs of the construction project for the work omission. The relevant literatures collation found that the current researchers mainly focus on the impact on increasing the amount of construction and cost, but for the work omission of the contract agreement is less. However, in real life when the project changes, which may affect one or more of the contract contents, thereby resulting in the occurrence of the work omission. 


\subsection{The main reason for the compensation of profit lose caused by the work omission}

By analyzing and summarizing the related literatures which are determined by the loss of profit caused by work omission, the following points can be identified as shown in Table 1.

Table 1 Study on the determination of profit loss in the work omission

\begin{tabular}{|c|c|c|c|c|}
\hline No. & Researcher & Research subjects & Method & Conclusion \\
\hline 1 & Y.L. Yin[4] & $\begin{array}{l}\text { Comprehensive } \\
\text { unit price change }\end{array}$ & $\begin{array}{l}\text { Weighted average } \\
\text { method }\end{array}$ & $\begin{array}{l}\text { Analysis of comprehensive unit price analysis } \\
\text { table, clear the profits and charging base, } \\
\text { according to the local area of the selected quota } \\
\text { identified in profit rate, then weighted arithmetic } \\
\text { average value calculated by that rate for the } \\
\text { contract profits. }\end{array}$ \\
\hline 2 & $\begin{array}{c}\text { Y.W. } \\
\text { Duan[5] }\end{array}$ & Change claim & $\begin{array}{l}\text { Depends on whether } \\
\text { or not to shorten the } \\
\text { duration of the } \\
\text { contract }\end{array}$ & $\begin{array}{l}\text { If the reduction of work to shorten the duration of } \\
\text { the contract, the resulting opportunity profit will } \\
\text { be reduced to the profit claims. }\end{array}$ \\
\hline 3 & $\begin{array}{c}\text { H.M. } \\
\text { Wang[6] }\end{array}$ & Profit claim & $\begin{array}{l}\text { Work omission's } \\
\text { scale }\end{array}$ & $\begin{array}{l}\text { When no significant change is constituted, the } \\
\text { profit compensation amount is determined } \\
\text { according to the cost profit rate and the amount of } \\
\text { the project cost of the corresponding items in the } \\
\text { price list.; When the contract is to cut the work } \\
\text { constitutes a major change in the contract, the } \\
\text { corresponding profit compensation should be } \\
\text { determined separately. }\end{array}$ \\
\hline 4 & $\begin{array}{c}\text { X.Y } \\
\text { Yuan[7] }\end{array}$ & Viriation contract & $\begin{array}{l}\text { Contractual } \\
\text { agreement }\end{array}$ & $\begin{array}{l}\text { If not, Compensation profit; If have, And the } \\
\text { employer does not do so in order to give the work } \\
\text { to other contracting parties or the designated } \\
\text { sub-contractor to complete, cannot get the } \\
\text { reduction of the work of profits. }\end{array}$ \\
\hline
\end{tabular}

Through the comparison of Table 1, it shows that the determination of profit loss is divided into two cases:

1)If the work omission shortens the duration of the contract, the resulting opportunity profit will be reduced to the profit compensation;

2) When the employer cuts any job in the contract and did not constitute a major change, profit compensation in accordance with the price of construction quantity list of corresponding project cost profit rate and to reduce the construction quantity determined; when the employer cuts work contract constitutes a major change, profit compensation amount of corresponding should be separately to determine.

\subsection{Method for determining the profit loss caused by the work omission}

It is very difficult to calculate its profit margins and to find out the profit calculation base, because the profit is independent contractors offer, which caused the loss of profits determine the dispute also tend to be larger.And the profit loss method to determine in this paper mentions, which in the practical application have the conditions to use, Table 2 of ratio analysis cut profit loss calculation method.

Table 2 Work Omission Management Fees Calculated Loss of Comparative Analysis

\begin{tabular}{|c|c|c|c|c|}
\hline Method & Applicable conditions & Calculation basis & Real time & $\begin{array}{l}\text { Wide } \\
\text { application }\end{array}$ \\
\hline Weighted average & $\begin{array}{l}\text { Complete list of projects, } \\
\text { Average level of industry } \\
\text { profits }\end{array}$ & $\begin{array}{l}\text { The profit is allocated } \\
\text { to each item }\end{array}$ & \multirow{2}{*}{$\begin{array}{l}\text { Delete any time the } \\
\text { project is carried out. }\end{array}$} & widely \\
\hline $\begin{array}{l}\text { Engineering } \\
\text { quantity list }\end{array}$ & $\begin{array}{l}\text { The profit of the } \\
\text { Contractor's own quotation }\end{array}$ & contract & & secondary \\
\hline
\end{tabular}


Through the comparison of Table 2, in practice, the application of the weighted average method is the most extensive, and causes the least controversial. The method of construction quantity list to determine the profit rate, although the interest rate has already stipulated in the contract, but due to the contractors independent quotation profits, the contractor bid to provisions of lower interest rates by determined the amount of the loss of the generally low, caused work omission often controversy. This method is mainly applied to the complex engineering.

\section{Method for determining the amount of profit compensation caused by work omission}

(1) Fixed proportion of contract based on work omission's scale

According to the weighted average method to determine the loss of profit, means in this basis in accordance with the different profit losses to the contractor to give different proportions of compensation. Proportion decreased with the increase of profit loss. That means if it is low losses, give full compensation; otherwise it is high losses, give a lower proportion of compensation. This compensation method can avoid the requirement of the contractor to cut the contract and get a higher profit. The specific ratio is shown in Figure 2.

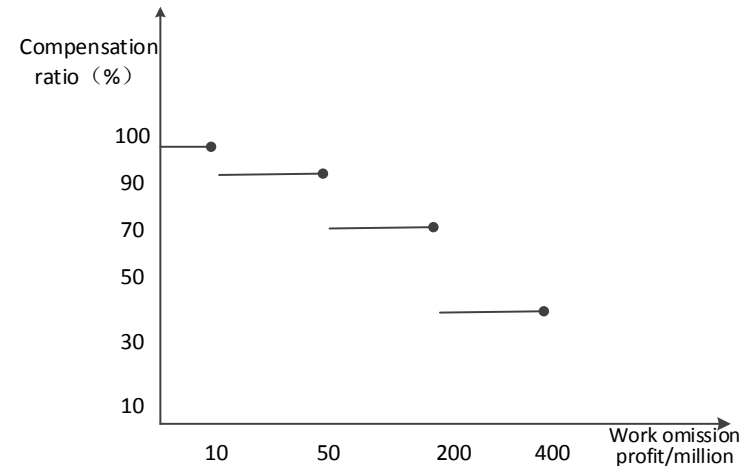

Fig. 2 Work Omission Loss Compensation Ratio

(2) Expected profit compensation method

The expected profit is the benefit performed under the construction contract, which is normally available to the contractor. Compensating for the expected profit is, the contractor cannot continue to perform the contract or terminate the contract by the owners default, the contractor proposed compensation for expected profits for the unfinished work.

Compensation of profit $=$ total cost budget $(1-$ floating rate $) \times$ contract price $\times$ Available profit margin

To sum up, in determining the compensation amount of profit preferred according to cut work scale contract fixed ratio method profit compensation in contractor to cut profit compensation value controversial when can the expected profit compensation method is used to. Due to the expected profit law requires more information, the program is more complex.

\section{Summary}

This paper focuses on the analysis of the work omission's profit loss calculation method.Through the analysis of research status of that the profit is to quote independently by the contractor, so the calculation base and the profit rate is difficult to determine, even if determined, no accurate calculation method to determine the compensation. The weighted average method and the construction quantity list method are mainly adopted in the practical construction. On the basisof determining the work omission's loss of profits, it gives the cut contract agreed profit compensation method, and according to the cut size of the work contract of fixed ratio, expected profit compensation method. According to the reduction of the size of the contract fixed ratio method to determine the amount of profit compensation is the reality of the current stage of our country has been widely implemented in the valuation model of the bidding The compensation value determined the product of the expected profitlaw and the product of the expected profit rate. 


\section{References}

[1] Z.C. Ma. Analysis of International Engineering Claims under the Conditions of FIDIC Contract. Management Observer. (2011) No. 9, p.151-153.

[2] Code of Bills of Quantities and Valuation for Construction Works. GB50500-2013. Beijing: Chian Planning Press, 2013.

[3] H.C. Gao. Study on the Income Management of the Contractor under the Condition of Engineering Variation (M.S. Thesis, Tianjin University of Technology, China 2012).

[4] Y.L Yin. Research on the Determination of Comprehensive Unit Price of Engineering Variation under the Principle of Cost PlusProfit. ConstructionEconomy. Vol. 10 (2012) No.8, p. 43-46.

[5] Y.W. Duan. The Principle and Quantitative Analysis of Profit Claim in Construction Contract. Construction Economy. Vol. 6 (2009) No. 44, p. 14-17.

[6] H.M. Wang, J. Sheng. Engineering Variation Management.Modernization of construction management. Vol. 4 (2009) No. 6, p. 113-115.

[7] X.Y. Yuan.A study on the Claim of the Contractor in the International Project Contract to the Headquarters Management Fee andProfit.Vol. 8 (2008) No. 24, p. 9-14. 